\title{
STRATEGI PENGEMBANGAN PARIWISATA SPIRITUAL DI KABUPATEN GIANYAR
}

\author{
Oleh \\ Putu Eka Purnamaningsih ${ }^{1)}$ \& Kadek Wiwin Dwi Wismayanti ${ }^{2)}$ \\ ${ }^{1,2}$ Program Studi Administrasi Negara, FISIP, Univeritas Udayana \\ Bali, Indonesia \\ Email: ${ }^{1}$ ekapurnama@unud.ac.id \& ${ }^{2}$ wiwin.fisip@ unud.ac.id
}

\begin{abstract}
Abstarct
Tourism is a variety of tourism activities and contains various facilities and services provided by the community, business people, government and local government. The development of Bali tourism has developed in the Bali region in Gianyar Regency. In this study aims to determine the strategy of developing tourism, especially spiritual tourism. The location of this research is in the area of Gianyar Regency. This study uses qualitative research with descriptive methods, in addition to using swot analysis to discuss content descriptions. Data collection techniques by observation, interviews, questionnaires, literature study and documentation. The informant in this study was the Head of the Gianyar Regency Tourism Office or related, pengempon Pura, tourism agents, as well as the local community. Until now, the Gianyar Regency does not have tourism specifically formed as spiritual tourism, because there are no clear rules, procedures, and criteria in establishing suitable objects to be categorized as spiritual tourism. Gianyar Regency has 7 tourism objects that have the potential to be developed as spiritual tourism objects. Therefore, research is conducted to determine the strategy in developing the seven objects so that they become more advanced objects of spiritual tourism. The strategy is formulated using a swot matrix with indicators measuring Strength, Weakness, Opportunity, and Threats. Through the analysis of the swot matrix, it can then be made in accordance with strategies to develop 7 tourism objects in Gianyar to become a new destination for spiritual tourism.
\end{abstract}

Keywords: Tourism Potential, Spiritual Tourism, Development Strategy \& SWOT Analysis

\section{PENDAHULUAN}

Perkembangan pariwisata di Indonesia saat ini sudah sangat pesat, khususnya wilayah pariwisata sentral seperti Pulau Bali. Seakan tidak pernah surut jumlah wisatawan yang tertarik untuk berkunjung ke Pulau Bali malah semakin berkembang setiap tahunya. Banyak faktor yang mendorong laju perkembangan kepariwisataan di Bali antara lain daya tarik wisata alamnya, budaya dan tradisi yang unik serta penduduk yang ramah menjadikan bali sebagai destinasi pariwisata yang sangat layak untuk dikunjungi. Hal inilah yang berhasil menstimulasi Bali dalam meningkatkan jumlah wisatawan baik wisatawan domestik maupun mancanegara.

Di bali sendiri terdapat 8 wilayah kabupaten atau kota yang masing-masing mempunyai karakteristik dan potensi wisata yang berbeda. Salah satunya. Kabupaten Gianyar yang http://ejurnal.binawakya.or.id/index.php/MBI merupakan wilayah pariwisata spiritual maju dengan ikon destinasi pariwisata nya yang sudah terkenal. Kabupaten Gianyar sendiri merupakan kabupaten di Bali yang dibina oleh Bank Indonesia (BI) Kantor Perwakilan (KPW) Bali. Keunggulan dari Kabupaten Gianyar ini sehingga dijadikan wilayah wisata binaan Bank Indonesia pertama karena memiliki banyak situssitus sejarah serta memiliki destinasi spiritual yang dapat dikunjungi oleh wisatawan domestik maupun mancanegara

Branding Pulau Bali melalui Kabupaten Gianyar sebagai destinasi pariwisata spiritual di Indonesia tidak hanya ditentukan oleh faktor geografis yang melulu seputar situs sejarah dan keindahan alam lainnya. Disamping keindahan alam dan budayanya, Bali juga merupakan daerah yang terkenal dengan mayoritas penduduknya berkeprcayaan Hindu. Hal ini dapat dibuktikan dengan banyaknya Pura atau tempat ibadah

Vol.15 No.3 Oktober 2020 
sejenis lain yang begitu menjamur di Kabupaten Gianyar. Eksistensi dari banyaknya Pura sebagai tempat ibadah umat Hindu di Kabupaten Gianyar menjadikan daerah tersebut sebagai destinasi pariwisata spiritual yang berpotensi meningkatkan jumlah partisipasi wisatawan dalam mengunjungi Pulau Bali. Hal tersebut merupakan suatu identitas dan keunikan tersendiri sebagai ciri khas yang mampu mendongkrak pengembangan potensi wisata spiritual di Pulau Bali.

Sebagai wilayah pariwisata yang maju, maka sangat diperlukan adanya pengembanganpengambangan potensi wisata lain yang mampu menambah destinasi wisata baru dengan daya tarik yang berbeda. Melalui ciri khas Bali yang merupakan mayoritas penduduk Hindu, dapat dijadikan suatu potensi wisata baru yang dapat menarik laju kenaikan wisatawan yaitu melalui pariwisata spiritual. Wisata spiritual sendiri merupakan perjalanan wisata yang didasari akan motif spiritualitas. Melalui kunjungan terhadap tempat-tempat suci dan tempat-tempat yang merupakan kawasan keagamaan, dapat dijadikan suatu potensi dalam menggali destinasi wisata baru nantinya di Kabupaten Gianyar.

Pariwisata spiritual di Kabupaten Gianyar sudah sangat maju dan berkembang seperti contohnya adalah wisata spiritual Tirtaempul, Goa Gajah, Gunung Kawi dan lainya. Hal ini yang menjadikan faktor utama berkembangnya bali sebagai daerah tujuan wisata baik wisatawan mancanegara maupun wisatawan nusantara. Kabupaten Gianyar menjadi salah satu wilayah yang sedang dalam tahap perkembangan pariwisata spiritual. Atraksi wisata yang ditawarkan berupa wisata alam, wisata khusus, dan wisata spiritual. Wisata spiriual memang wisata yang perlu dikembangkan di Kabupaten Gianyar karena dalam pengembangan dan pengelolaan daya tarik wisata spiritual tersebut belum maksimal. Untuk itu suatu wilayah khususnya Kabupaten Gianyar haruslah lebih peka dalam memperhatikan daya tarik wisata spiritualnya yang menjadi andalan pariwisata di wilayah Kabupaten Gianyar.

Vol.15 No.3 Oktober 2020
Pada penelitian ini akan difokuskan pada perancangan strategi terkait dengan pengembangan pariwisata spiritual agar berjalan secara optimal di Kabupaten Gianyar, Provinsi Bali. Dari urian tersebut, maka rumusan masalah yang hendak di jawab pada penelitian ini, yaitu bagaimana Strategi pengembangan pariwisata spiritual di Kabupaten Gianyar Provinsi Bali ?

\section{METODE PENELITIAN}

Metode penelitian yang digunakan dalam penelitian ini adalah penelitian kualitatif Singarimbun dan Efendi:1989:4 menyatakan dimana bahwa penelitian kualitatif merupakan penelitian dengan pendekatan deskriptif, penelitian deskriptif yang dimaksudkan sebagai pengukuran fenomena sosial tertentu yang mampu mengembangkan konsep serta menghimpun fakta tetapi tidak melakukan hipotesis, sebagaimana hasil wawancara akan digunakan serta dijabarkan sehingga menghasilkan analisis deskriptif sebagaimana dalam penelitian kualitatif.Teknik pengumpulan data dalam Penelitian ini dilakukan dengan mengumpulkan data primer dan data sekunder. Pengumpulan data yang dilakukan dalam penelitian ini menggunakan teknik-teknik pengumpulan data sebagai berikut: Observasi langsung ke lokasi penelitian pada objek wisata spiritual di Kabupaten Gianyar dalam rangka penelusuran data yang tidak diperoleh dalam wawancara, maupun data-data sekunder. Wawancara mendalam (in-depth interview) yang dilakukan terhadap narasumber untuk mengetahui secara persis fenomena-fenomena tentang pegembangan pariwisata spiritual yang ingin diketahui. Data yang akan diperoleh langsung dari informan menjadi sumber data dalam penelitian ini adalah para aktor dalam proses pengembangan pariwisata spiritual di Kabupaten Gianyar.

\section{HASIL DAN PEMBAHASAN}

Pengembangan Usaha pariwisata spiritual sudah diatur berdasarkan Peraturan Gubernur Bali Nomor 35 Tahun 2014 Tentang Usaha Pariwisata Spiritual. Di dalam peraturan Gubernur tersebut menjadi dasar bagi Dinas http://ejurnal.binawakya.or.id/index.php/MBI 
Pariwisata Kabupaten Gianyar dalam mengkategorikan pariwisata yang termasuk dalam parwisata spiritual secara umum yang di muat dalam Bab 1 Peraturan Gubernur No 35 Tahun 2014 seperti berikut ini :

a) Wisata Spiritual adalah perjalanan wisata yang lebih mengarah pada kegiatan untuk meningkatkan kehidupan spiritual (kerohanian) dengan cara mengunjungi dan/atau mclaksanakan ibadah ke tempattempat suci, tempat bersejarah atau ke makam-makam orang suci, bukit, gunung, goa, atau tempat yang dianggap keramat, kemudian langsung melakukan persembahyangan atau meditasi.

b) Wisata religi merupakan perjalanan wisata terkait dengan kepercayaan/keyakinan dengan mengunjungi tempattempat suci atau tempat lainnya yang disucikan untuk melaksanakan ibadah.

c) Wisata meditasi merupakan perjalanan wisata mengunjungi tempat-tempat yang hening, tenang dan damai untuk penenangan diri, penjernihan pikiran seperti goa-goa alam, ashram atau tempat lainnya dianggap dapat menciptakan keheningan untuk melakukan meditasi.

d) Wisata yoga merupakan perjalanan wisata mengunjungi tempat khusus untuk melakukan yoga dengan dibimbing oleh guru yoga.

e) Pengusaha Pariwisata yang selanjutnya disebut pengusaha adalah perseorangan atau badan usaha yang melakukan kegiatan usaha pariwisata bidang usaha wisata spiritual

f) Tanda Daftar Usaha Pariwisata adalah dokumcn resmi yang membuktikan bahwa usaha pariwisata yang dilakukan oleh pengusaha telah tercantum dalam Daftar Usaha.

Di Kabupaten Gianyar sendiri terdapat 61 objek pariwisata berdasarkan Keputusan Bupati Nomor 42 Tahun 2008 Tentang Penetepan Obyek Dan Daya Tarik Wisata Kabupaten Gianyar. Sebanyak 61 obyek tersebut sistem http://ejurnal.binawakya.or.id/index.php/MBI pengelolaanya terbagi menjadi dua. 7 objek pariwisata dikelola oleh Dinas Pariwisata Kabupaten Gianyar, karena merupakan objek peninggalan sejarah yang harus dilindungi dan menjadi kewajbian pemerintah daerah untuk melestarikan. Sedangkan sisanya, merupakan objek pariwisata buatan yang dibuat yang dikelola oleh desa adat dan pihak swasta. Hingga saat ini, di Kabupaten Gianyar belum memiliki pariwisata yang secara khusus merujuk pada pariwisata spiritual. Objek yang digunakan hanya berfungsi sebagai tempat ibadah bagi umat Hindu, dan belum dikembangkan menjadi destinasi pariwisata spiritual. Oleh karena itu, peerintah kabupaten Gianyar melalui Dinas Pariwisata memiliki rencana untuk mengelola 7 objek tersebut yang selanjutnya akan dikembangkan menjadi objek pariwisata spiritual.

"Jumlah objek wisata yang dikelola langsung oleh Dinas Pariwisata Kabupaten Gianyar ada 7 objek. Objek objek itu antara lain Goa Gajah, Candi Tebing Tegallinggah, Gunung Kawi Sebatu, Gunung Kawi Tampaksiring, Yeh Pulu, Pura Tirta Empul, dan Bukit Jati” (wawancara tanggal 14 Juli 2020)

Ketujuh objek pariwisata tersebut akan dikembangkan dan diprioritaskan oleh Pemerintah Kabupaten Gianyar untuk menjadi obyek wisata spiritual dipilih dan dikelola karena sesuai dengan kriteria yang mengacu pada Peraturan Gubernur No 35 Tahun 2014 Tentang Usaha Pariwisata Spiritual. Saat ini pemerintah Kabupaten Gianyar sedang dalam tahapan perencanaan dalam mengembangakan berbagai fasilitas penunjang dalam membuat destinasi parwisata spiritual akan tetapi prosesnya tertahan berkaitan dengan adanya pandemi virus COVID19 di Indonesia.

Objek yang bekerjasama Pemerintah Kabupaten Gianyar tersebut, segala hal yang berkaitan dengan pengelolaan diatur berdasarkan PKS atau Perjanjian Kerja Sama antar kedua belah pihak. Di dalam PKS ini mengatur pembagian retribusi sebagai $\mathrm{PAD}$ dan beberapa

\section{Open Journal Systems}


hal terkait pembagian hak dan kewajiban kedua belah pihak.

Selanjutnya, tujuh obyek wisata yang akan di kembangkan menjadi objek wisata spiritual di Kabupaten Gianyar diatas dapat dianalisis pengembanganya dengan menggunakan analisis SWOT untuk mengetahui strategi apa yang diperlukan dan kompatibel untuk diterapkan dalam rangka mengembangkan obyek pariwisata tersebut menjadi objek pariwisata apiritual di Kabupaten Gianyar sebagai berikut.

\section{a. Strength (Kekuatan)}

Strength merupakan faktor-faktor yang memiliki kekuatan dalam mendorong pengembangan pariwisata spiritual di Kabupaten Gianyar. Faktor-faktor yang menjadi kekuatan dalam pengembangan pariwisata spiritual di Kabupaten Gianyar antara lain :

1. Pariwisata di Kabupaten Gianyar merupakan sumber ekonomi masyarakat di wilayah Kabupaten Gianyar. Dimana pengembangan pariwisata di Kabupaten Gianyar sangat didukung oleh masyarakat sekitar. Sehingga dengan adanya rencana pemerintah untuk membentuk pariwisata spiritual maka turut menjadi peluang ekonomi bagi masyarakat diwilayah tersebut. Karena objek yang selama ini hanya berfungsi sebagai tempat ibadah, dikembangkan menjadi objek pariwisata spiritual yang secara langsung akan mendatangkan wisatawan. Seperti pernyataan Kepala Dinas Pariwisata Kabupaten Gianyar.

"Bagaimanapun pengembangan obyek wisata bertujuan untuk meningkatkan perekonomian masyarakat sekitar objek wisata itu sendiri. Jadi sampai saat ini masyarakat sangat antusias dalam mendukung pengembangan pariwisata spiritual di Kabupaten Gianyar".(Wawancara Tanggal 14 Juli 2020)

Pernyataan tersebut diperkuat oleh perndapat masyarakat setempat (Nengah Aniasih) yang merupakan pedagang terkait rencana pengembangan pariwisata spiritual di Kabupaten Gianyar.

"saya sih setuju sekali dengan rencana kalau mau dibuka pariwisata spiritual seperti ini ya, karena nanti kan jadinya membuka lapangan kerja baru untuk masyarakat, misalnya pedagang seperti itu, jadi memang kami sangat mendukung rencaa pemerintah dalam mengembangkan wisata ini" (wawancara 17 Juli 2020)

2. Memiliki Prosedur yang jelas dalam mengatur wisatawan yang berkunjung. Hal ini menjadi faktor kekuatan dalam melakukan filterisasi atau penyaringan wisatawan yang masuk. Mengingat nantinya pariwisata spiritual merupakan pariwisata yang juga berkaitan dengan kegiatan peribadatan.

Pemerintah Kabupaten Gianyar telah memasang informasi tata tertib dengan dua bahasa yaitu Indonesia dan Inggris yang bertujuan dalam mengatur wisatawan yang berkunjung ke objek wisata yang akan dijadikan objek pariwisata spiritual nantinya. Hal ini seperti ditekankan oleh Kepala Dinas Pariwisata dalam wawancara tanggal 14 Juli 2020 sebagai berikut :

"setiap objek yang adakami selalu memberlakukan peraturan-peraturanguna menjaga kesucian, keasrian, dan kebersihan objek wisata. Peraturan dalam berperilaku dan berpakaian pada saat berkunjung juga kami berlakukan" (wawancara 14 Juli 2020)

3. Memiliki Prosedur pembukaan pariwisata di era New Normal yang sudah dikeluarkan oleh dinas Pariwisata Kabupaten Gianyar. Di kondisi pandemi saat ini, pemerintah Kabupaten Gianyar telah merilis prosedur dalam pembukaan obyek pariwisata. Sehingga pengembangan pariwisata menjadi pariwisata spiritual yang dikelola oleh Dinas Pariwisata Kabupaten Gianyar dapat direalisasikan dengan cepat dan

http://ejurnal.binawakya.or.id/index.php/MBI 
sesuai dengan protokol kesehatan yang berlaku.

4. Di Kabupaten Gianyar belum memiliki pariwisata yang memang dikembangkan sebagai pariwisata spiritual, tetapi memiliki 7 objek yang sangat mendukung untuk dikembangkan sebagai destinasi pariwisata spiritual. Sehingga menjadi kekuatan bagi pemerintah Kabupaten Gianyar untuk mengembangkan objek wisata tersebut menjadi destinasi wisata baru berbasis spiritual.

\section{b. Weakness (Kelemahan)}

1. Pariwisata berbasis spiritual di Kabupaten Gianyar hingga saat ini belum ada dan belum memiliki payung hukum yang secara spesifik mengatur tentang pariwisata spiritual dan pngelompokanya. Berdasarkan pernyataan Sekretaris Dinas Pariwisata Kabupaten Gianyar dalam wawancara 14 Juli sebagai berikut :

" kalau payung hukum secara spesifik yang mengarah ke pengembangan wisata spiritual itu belum ada, cuman kedepan kita akan mengarah kesana. Akan mengelompokkan wisata-wisata yang ada di Kabupaten Gianyar."

2. Belum ada organisasi atau bidang khusus dibawah dinas pariwisata yang bertugas melakukan inspeksi atau pengawasan pariwisata spiritual dikemudian hari di Kabupaten Gianyar. Sehingga nantinya dengan 7 objek yang dikelola secara bersamaan oleh Dinas Pariwisata tanpa membentuk badan khusus untuk mengawasi, dalam pengembanganya akan kurang optimal mengingat obyek pariwisata rentan terjadi pungutan liar retribusi. Seperti pernyataan Sekretaris Dinas Paiwisata Kabupaten Gianyar dalam kutipan wawancara berikut.

"tidak ada, sejauh ini kami dari dinas pariwisata langsung yang mengawasi kegiatan-kegiatan pariwisata. Tidak ada badan khusus yang bertugas mengawasi kegiatan pariwisata spiritual di
Kabupaten Gianyar.” (wawancara tanggal 14 Juli 2020)

3. Ketersediaan database dan informasi mengenai pariwisata spiritual yang masih terbatas. Sebagai contoh data kunjungan wisatawan di objek wisata spiritual yang secara khusus tidak tersedia di Dinas Pariwisata, sedangkan data pengunjung dapat dijadikan acuan dalam mengembangkan pariwisata spiritual dikemudian hari.

"tidak ada data untuk pengunjung obyek wisata spiritual, data yang ada hanya data keseluruhan kunjungan wisatawan yang ada di setiap objek wisata di Kabupaten Gianyar" (wawancara tanggal 14 Juli 2020)

\section{c. Opportunity (Peluang)}

1. Kerjasama dengan stakeholder menjadi peluang dan memiliki peran yang signifikan dalam pengembangan pariwisata spiritual di Kabupaten Gianyar. Stakeholder mengambil peran penting dalam perluasan kegiatan dan kerjasama dengan pihak lain yang dapat mendukung pengembangan pariwisata spiritual.

Di Kabupaten Gianyar sendiri, kerjasama dengan stakeholder dalam rencana pengembangan pariwisata spiritual sudah ada seperti dinyatakan oleh kepala dinas pariwisata sebagai berikut:

"kerjasama dengan stakeholder dalam pengembangan pariwisata spiritual sudah ada, contohnya dalam kegiatan Bali Spirit Festival dimana kegiatan ini pada dasarnya adalah festival yoga. Kami pemerintah kabupaten Gianyar selalu mendukung pelaksanaan kegiatan inimulai dari bantuan anggaran, bantuan promosi dan lain sebagainya." (wawancara 14 Juli 2020)

Selain itu, pernyataan juga diperkuat oleh Kelihan Desa Adat Bedulu Kabupaten Gianyar yang menyampaikan bahwa memang pemerintah telah melakukan hubungan kerjasama dengan desa adat

Vol.15 No.3 Oktober 2020 
Bedulu dalam pengelolaan salah satu objek yaitu Candi Tebing Tegallinggah Gianyar :

"nggih, memang sudah ada kerjasaa nike sama pemerintah kabupaten ya. Kita mengikuti saja dan berkontribusi untuk pengembangan kawasan wisata menjadi wsiata spiritua;. Kerjasama ini kan nantinya juga berdampak positif, contohnya meningkatkan jumlah wisatawan. "(wawancara 17 Juli 2020)

Selain dengan desa adat setempat, kerjasama juga dilakukan dengan sejumlah agen pariwisata dalam mengembangkan objek menjadi pariwisata berbasis spiritual di Kabupaten Gianyar. kerjasama ini berbentuk bantuan promosi oleh pihak swasta dalam hal ini agen pariwisata, seperti dijelaskan oleh Dewa Gede Anom selaku penyedia Biro Perjalanan Wisata di Kabupaten Gianyar sebagai berikut

"wisata spiritual ini kan memang bagus ya, maksudnya sekarang kan wisatawan bule-bule seperti itu kan yang dicari wisata spiritual seperti ini, nah pemerintah mau kerjasama dengan kami, dengan senang hati kami bantu. Kami wadahi dalam mempromosikan objek wisata spiritual nantinya. Selain itu nant kita masukkan objek tersebut ke dalam paket wisata sehingga pariwsiata spiritual semakin dikenal oleh wisatawan khususnya wisatawan asing." (wawancara 17 Juli 2020)

2. Komunikasi dengan masyarakat dan para pemangku kepentingan yang baik turut menjadi faktor Peluang dalam mengembangkan pariwisata spiritual di Kabupaten Gianyar. Pemerintah Kabupaten Gianyar sampai sejauh ini sudah melakukan komunikasi kepada pemangku kepentingan (seperti pengempon pura dan kawasan suci) dalam rangka mengembangkan kawasan tersebut menjadi obyek wisata spiritual. Seperti kutipan wawancara kepada
Kepala Dinas Pariwisata Kabupaten Gianyar sebagai berikut :

"setiap objek wsiata suci yang ingin dikembangkan menjadi sebuah daya tarik wisata kami selalu melakukan komunikasi yang intens dengan pengempon pura, prajuru desa pakraman, dan masyarakat sekitar. komunikasi tidak dilakukan sampai disitu saja, tetapi sampai pelaksanaan hingga kesepakatan antara pemerintah dengan masyarakat adat." (wawancara 14 Juli 2020)

3. Keberadaan pariwisata spiritual sebagai industri pariwisata baru di Bali khususnya Kabupaten Gianyar yang akan dikembangkan menjadi peluang yang baik. pariwisata sepiritual dapat menjadi obyek wisata yang mampu mendatangkan wisatawan mengingat daya tariknya yang begitu banyak. Selain sebagai media persembahyangan obyek wisata spiritual dapat diaplikasikan sebagai wisata alam bagi wisatawan yang mengharapkan perjalanan wisata spirit seperti yoga dan mditasi. Keunikan pariwisata spiritual seperti ini menjadi daya tarik atau peluang mendatangkan wisatawan apabila dikelola secara berkelanjutan.

\section{d. Threats (Ancaman)}

1. Pandemi COVID19 saat ini menjadi ancaman pertama dan utama dalam proses pengembangan pariwisata spiritual di Kabupaten Gianyar. Pengembangan pariwista spiritual belum dapat dilaksanakan mengingat wabah pandemi mengharuskan untuk menutup sejumlah objek wisata di Bali. Meski demikian di era New Normal saat ini, pemerintah Kabupaten Gianyar sudah memiliki kebijakan untuk membuka obyek wisata dengan mengikuti standar protokol kesehatan. Dengan begitu tidak menutup kemungkinan bagi pemerintah untuk melanjutkan pelaksanaan pengembangan pariwisata spiritual di Kabupaten Gianyar dengan tetap melihat kondisi terbaru dan http://ejurnal.binawakya.or.id/index.php/MBI 
terus melakukan update situasi di masa pandemi saat ini.

2. Persaingan obyek wisata juga menjadi ancaman bagi keberadaan pariwisata spiritual di Bali, khususnya Kabupaten Gianyar. Minat masyarakat yang belum cukup besar untuk mengunjungi obyek wisata spiritual menjadi hambatan dalam mengembangkan industri pariwisata spiritual itu sendiri. Masyarakat bahkan lebih tertarik dengan pariwisata yang berkaitan dengan traveling dan wisata belanja. Selain itu saat ini wisatawan Bali lebih dominan berwisata di Pantai seperti Kuta dan Canggu dibandingkan ke obyek wisata spiritual di Kabupaten Gianyar. Hal inilah yang menjadi ancaman pariwisata spiritual untuk dikembangkan dikemudian hari.

\subsection{Matriks Swot}

\begin{tabular}{|c|c|c|}
\hline & $\begin{array}{c}\text { KEKUATAN } \\
\text { (STRENGTH- } \\
\text { S) }\end{array}$ & $\begin{array}{c}\text { KELEMAHAN } \\
\text { (WEAKNESS- } \\
\text { W) }\end{array}$ \\
\hline $\begin{array}{c}\text { PELUANG } \\
\text { (OPPORTUNITY- } \\
\text { O) }\end{array}$ & $\begin{array}{c}\text { STRATEGI } \\
\text { SO }\end{array}$ & $\begin{array}{c}\text { STRATEGI } \\
\text { WO }\end{array}$ \\
\hline ANCAMAN & STRATEGI & STRATEGI \\
(THREATS-T) & ST & \\
\hline
\end{tabular}

1. Strategy SO (Strength-Opportunity) menciptakan strategi dengan menggunakan kekuatan sebagai peluang dalam pengembangan pariwisata spiritual di Kabupaten Gianyar.

$\begin{aligned} & \text { STRATEGY SO } \\ & \text { OPPORTUNITY) }\end{aligned}$
STRENGTH-

Memberikan sosialisasi kepada masyarakat sekitar objek wisata dan membuka kesempatan lapangan kerja, sehingga selain sebagai obyek wisata yang menguntungkan pemerintah, juga memberikan kontribusi yang besar bagi perekonomian masyarakat sekitar.
2. Meningkatkan dan mempertegas prosedur yang lebih rinci dalam mengatur wisatawan yang berkunjung ke obyek wisata spiritual di Kabupaten Gianyar yang sebagian besar merupakan kawasan suci.

3. Menginformasikan kepada masyarakat dan pemangku kepentingan terkait izin wisata yang boleh kembali di buka di era new normal, sehingga mempercepat pengembangan pariwisata spiritual.

2. Strategy ST (Strength-Threats) menciptakan strategi dengan menggunakan kekuatan untuk mengatasi ancaman dalam pengembangan pariwisata spiritual di Kabupaten Gianyar.

\section{STRATEGY SO (STRENGTH- OPPORTUNITY)}

1. Menerapkan regulasi pembukaan pariwisata spiritual di era New Normal segera dengan menerapkan protokel kesehatan, sehingga ancaman pandemi dapat diaatsi dengan membuka obyek wisata akan tetapi dengan tetap memperhatikan protokol kesehatan yang berlaku.

2. Membuat promosi yang lebih gencar serta mengemas pariwisata spiritual dengan berbagai bentuk seperti festival dan sebagainya untuk menarik minat masyarakat dan wisatawan.

3. Strategy WO (Weakness-Opportunity) menciptakan strategi dengan meminimalkan kelemahan untuk memanfaatkan peluang dalam pengembangan pariwisata spiritual di Kabupaten Gianyar.

\section{STRATEGY WO (WEAKNESS- OPPORTUNITY)}

1. Membuat payung hukum atau landasan hukum yang jelas serta aturan dalam menentukan kriteria pariwiata yang termasuk kategori pariwisata spiritual di Kabupaten Gianyar

2. Membentuk Bidang khusus dari dinas pariwisata yang secara khusus mengelola 
pengembangan pariwisata spiritual di Kabupaten Gianyar sehingga pelaksanaan pengembanganya lebih optimal.

3. Membuat database informasi mengani wisatawan dan industri pariwisata spirituakl secara spesifik sehingga mampu menarik minat wisatawan untuk berkunjung.

\section{Strategy WT (Weakness-Opportunity)} menciptakan strategi dengan meminimalkan kelemahan dan menghindari ancaman dalam pengembangan pariwisata spiritual di Kabupaten Gianyar.

\section{STRATEGY WT (WEAKNESS-THREATS)}

1. Memberikan sosialiasi, informasi, dan pelatihan yang tepat kepada setiap pemangku kepentinngan dalam pembukaan pariwisata spiritual di era new normal sehingga mampu meminimalkan resiko dan ancaman dalam pengembangan pariwisata spiritual di Kabupaten Gianyar.

\subsection{Rekomendasi dalam Mengembangkan} Industri Pariwisata Spiritual di Kabupaten Gianyar.

1. Pariwisata bersifat multi disiplin dan multi sektoral, ini merupakan pemahaman yang harus ditanamkan pada setiap pemangku kepentingan pariwisata di Kabupaten Gianyar,sehingga dalam proses pengembangan yang dimulai dari tahap perencanaan sudah mempertimbangkan aspekaspek tersebut. Sinergi antar para pelaku serta industri baik yang terkait langsung maupun tidak langsung terhadap pariwisata haruslah lebih dioptimalkan,.

2. Research based strategy atau membuat strategi berdasarkan hasil research, akan membantu pemerintah Kabupaten Gianyar dalam melakukan pembangunan Pariwisata terutama dibidang pariwisata spiritual.

3. Sosialisasi, informasi, dan komunikasi yang baik anatara pemerintah masyarakat dan semua pemangku kepentingan yang terlibat

Vol.15 No.3 Oktober 2020 dam memiliki peran dalam pengembangan pariwisata spiritual di Kabupaten Gianyar.

4. Pemerintah perlu membuat pengelompokan atau standar kriteria dalam menentukan obyek pariwisata mana yang layak dan sesuai untuk dikembangkan dengan konsep spiritual dan obyek wsiata mana yang belum sesuai dan belum memenuhi syarat untuk dikembangkan sebagai pariwisata spiritual.

\section{PENUTUP}

\section{Kesimpulan}

Pengembangan pariwisata spiritual di Kabupaten Gianyar sebagai model destinasi pariwisata baru, hingga saat ini masih dalam tahap perencanaan dan pengembangan di beberapa objek. Obyek yang dikelola Pemerintah Kabupaten Gianyar melalui Dinas Pariwisata Kabupaten Gianyar terdapat 16 objek pariwisata yang saat ini lebih difokuskan lagi terhadap pengembangan 7 objek pariwisata yang paling potensial untuk dikembangkan. Obyek wisata tersebut antara lain Goa Gajah, Candi Tebing Tegallinggah, Gunung Kawi Sebatu, Gunung Kawi Tampaksiring, Yeh Pulu, Pura Tirta Empul, dan Bukit Jati.

Dalam pengembanganya, terdapat beberapa kekuatan, kelemahan, peluang dan ancaman yang selanjutnya dianalisis untuk dijadikan strategi dalam mengembangkan pariwisata spiritual. Kelemahan (weakness) dan ancaman (threats) tersebut antara lain belum adanya payung hukum yang negatur pariwisata spiritual di Kabupaten Gianyar, kurangnya database dan informasi mengenai pariwisata spiritual, serta belum adanya badan khusus untuk melakukan pengawasan terhadap pengemabngan pariwisata spiritual. Sedangkan ancaman dalam pengemabangan pariwisata spiritual di Kabupaten Gianyar saat ini adalah adanya Pandemi COVID19 yang menjadi tantangan tersendiri bagi pemerintah untuk mengatasi serta mengembangkan pariwisata ditengah-tengah menurunya minat wisatawan untuk berkunjung di saat pandemi seperti ini.

Berangkat dari analisis swot yang sudah dilakukan, terdapat beberapa strategi yang dapat http://ejurnal.binawakya.or.id/index.php/MBI 
menjadi rekomendasi bagi pemerintah Kabupaten Gianyar dalam mengembangkan Pariwisata Spiritual antara lain pemerintah perlu memperkuat landasan hukum pengembangan pariwisata spiritual, menggencarkan sosialisasi, komunikasi, dan promosi obyek wisata spiritual serta menerapkan protokol kesehatan dalam membuka kembali obyek wisata ditengah pandemi COVID19 seperti saat ini.

\section{DAFTAR PUSTAKA}

[1] Arsyad, Azhar. (2003). Manajemen Pengetahuan Praktis Bagi Pimpinan \& Eksekutif, Manajemen Strategik. Pustaka Pelajar. Yogyakarta.

[2] Badrudin, B. (2000). Pariwisata Indonesia Menuju World Class Tourism. Journal Akuntansi dan Manajemen.

[3] Bryson, J.M., Perencanaan Strategis untuk Organisasi Publik dan Nirlaba: Sebuah Panduan untuk Memperkuat dan Mempertahankan PrestasiOrganisasi, rev. ed. (San Francisco: Jossey-Bass, 1999)

[4] Pitana, I. Gede dan Gayatri, Putu. G. 2005. Sosiologi Pariwisata. Yogyakarta: Andi

[5] Raka, AA GD. 2015. Komodifikasi Warisan Budaya Sebagai Daya Tarik Wisata di Pura Penataran Sasih Pejeng Gianyar. Disertasi tidak diterbitkan. Denpasar: Universitas Udayana.

[6] Rangkuti, F. (2006). Analisis SWOT, Teknik Membedah Kasus Bisnis. Cetakan Kedua belas. PT Gramedia. Pustaka Utama. Jakarta.

[7] Rosidi, Abidarin dan Anggraeni, R. Fajriani. 2013. Reinventing Government: Demokrasi dan Reformasi Pelayanan Publik. Yogyakarta: Andi Publisher.

[8] Satori, Djam'an., Prof. Dr., M.A. dan Aan Komariah, Dr., M.Pd. 2014. Metodologi Penelitian Kualitatif. Bandung: Alfabeta

[9] Tripomo, T, (2005). Manajemen Strategi, Rekayasa Sains, Jakarta.

[10]Undang-Undang Nomor 10 Tahun 2009, Tentang Kepariwisataan.

[11]UNWTO. (2011). Toward 2030: Global Review. Madrid, Spain.
[12]Wahab, S. (2003). Manajemen Kepariwisataan. TP. Pradnya Paramita. Cetakan IV. Penerjemah Gromang F. Jakarta. 
HALAMAN INI SENGAJA DIKOSONGKAN 